\title{
PRELIMINARY EXPERIENCE WITH RESISTIN ASSESSMENT IN COMMON POPULATION
}

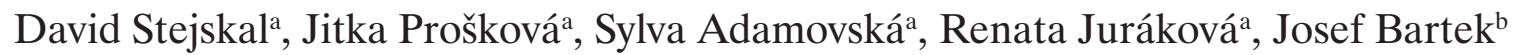 \\ a Department of Laboratory Medicine, Hospital Šternberk \\ ${ }^{b}$ Institute of Medical Chemistry and Biochemistry, Medical Faculty, Hněvotínská 3, 77515 Olomouc
}

Received: September 20, 2002

Key words: Resistin / Serum concentration

Resistin is a signal peptide produced by adipose tissue. Mice models have confirmed that resistin may play an important role in insulin resistance. Its function in the human organism has not been elucidated yet. Since in common population the resistin concentrations are not known (no validated commercial set is available), we performed resistin assessment using the ELISA method (with satisfying analytical characteristics) in a population of 123 non-obese probands without signs of insulin resistance and/or inflammation. Mean resistin values amounted to $14.3 \mathrm{ng} / \mathrm{ml}$ (reference limit of $7.3-21.3 \mathrm{ng} / \mathrm{ml}$ ).

\section{INTRODUCTION}

Several years ago, a new signal molecule was discovered and termed resistin $(12.5 \mathrm{kDa})$. It is a product of the RSTN gene that belongs to the category of proteins rich in cysteine (RELM family); some authors also use the terms ADSF (Adipose Tissue-Specific Secretory Factor) or FIZZ3 (Found in Inflammatory Zone).

Resistin is produced by preadipocytes and adipocytes in the form of propeptides (108 amino acids). Prior to secretion into circulation, it liberates a hydrophobic signal peptide (16 amino acids). Then resistin circulates as a dimer consisting of 92 amino acids connected by disulfide bridges.

Mice experiments have shown that resistin probably reduces insulin-stimulated uptake of glucose by tissues and thus reducing their sensitivity to insulin (resistin is an antagonist of the insulin effect). It influences particularly myocytes of striated muscles, i.e. hepatocytes and adipocytes ${ }^{1,2}$. It is considered to be a hormone associated with the origin of obesity of several types. This hypothesis is supported by the fact that resistin expression in abdominal adipose tissue is significantly higher than in other parts of adipose deposits ${ }^{5,7}$.

Obese mice (no genetic models) were found to have elevated concentrations of mRNA resistin in the systemic circulation. Elevated resistin levels start to be reduced after administration of some antidiabetics and prolonged fasting. Other animal studies have revealed that resistin levels increased during differentiation of adipocytes and even eliminated adipogenesis ${ }^{9}$.

Resistin expression is assumed to be regulated by many hormones and cytokines associated with the meta- bolism of insulin, glucose and adipocyte metabolism in general. It has been found that resistin expression in adipocytes is influenced by certain cytokines, increased in hyperglycemia, hypercorticolism (administration of dexamethasone to mice resulted in elevated mRNA resistin 2.5-3.5 $\times$ ) and decreased it after administration of insulin, thiasolindion, TNF-alpha (up by $80 \%$ ), adre-

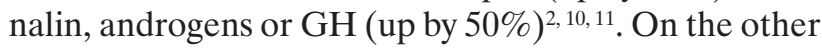
hand, in growth hormone-deficient mice when resistin expression in adipose tissue is reduced, treatment with growth hormone resulted in its "normalization"3.

It has not been proved yet whether the above-mentioned relations hold true in man. In a group of 44 patients with type 2 diabetes it was found that obesity and disorder of insulin sensitivity were associated with polymorphism of the gene for resistin (but no correlation was proved between type 2 diabetes mellitus and gene polymorphism). On the other hand, it was confirmed that adipocyte differentiation is associated with down regulation of resistin gene (in contrast to mice).

Moreover, it has been found that as in mice, humans had a high expression of mRNA resistin in abdominal tissue, which suggests association of resistin with obesity in diabetes mellitus of type 2 or the risk of ischemic disease $^{5,7}$; however, clinical studies have not proved clearly any correlation between expression of resistin gene, body weight, insulin sensitivity and diabetes mellitus of type 2 (ref. ${ }^{6,8}$ ).

Measurement of resistin concentration in the serum was reported only by several papers with ambiguous results ${ }^{12}$. 


\section{AIM OF THE STUDY}

The aim was to determine in a group of non-obese persons without clinical signs of insulin resistance and/or inflammatory disease the resistin concentration in the serum using the commercially available ELISA set.

\section{METHODS}

We examined 123 probands with BMI < 26, without clinical signs of insulin resistance. All probands were examined for resistin concentration (ELISA, two polyclonal antibodies, examination within four hours, producer: Biovendor, sensitivity of $0.2 \mathrm{ng} / \mathrm{ml}, \mathrm{CV}$ in a string of 8 examinations - concentration of $5 \mathrm{ng} / \mathrm{ml}<7 \%, \mathrm{CV}$ between strings - concentration of $5 \mathrm{ng} / \mathrm{ml}, 10$ days $<10 \%$ ). The study comprised patients without clinical signs of inflammatory diseases and/or insulin resistance.

\section{RESULTS AND DISCUSSION}

We examined 123 probands, mean age of 43 years (33 females, 90 males). Mean resistin values were $14.3 \mathrm{ng} / \mathrm{ml}$ (reference limits ranged from 7.26 to $21.3 \mathrm{ng} / \mathrm{ml}$ ) (Table 1, Graph 1).
The examined probands showed no correlation between resistin and age, sex, or BMI.

We consider it very important to determine the limits of resistin concentration in common population because the function of resistin in humans is not clear yet (in contrast to mice where resistin pathophysiology was sufficiently elucidated).

This may be due to many factors, e.g. human resistin has not been found yet or does not exist (only 54\% homology with mice resistin is reported), so that instead of resistin assessment we made "determination of cytokine from leukocytes".

A validated diagnostic set for determination of resistin was not available at the time of elaboration of the present paper; we found only one producer of the diagnostic set for resistin assessment, which did not meet the analytical criteria ${ }^{12}$ (unpublished data).

This aside, we consider the analytical characteristics of the set used by us as satisfactory; in next phases of the study theoretical relations should be verified (correlation to inflammation markers, insulin resistance and sensitivity and its dynamics, markers of adipocyte functions, etc.).

Table 1.

\begin{tabular}{|llllllll|}
\hline Parameter & $\mathbf{X}$ & Median & S & X-2s & X+2s & Min & Max \\
Resistin1 & 4.3 & 14 & 3.5 & 7.3 & 21.3 & 5.5 & 23.8 \\
\hline
\end{tabular}

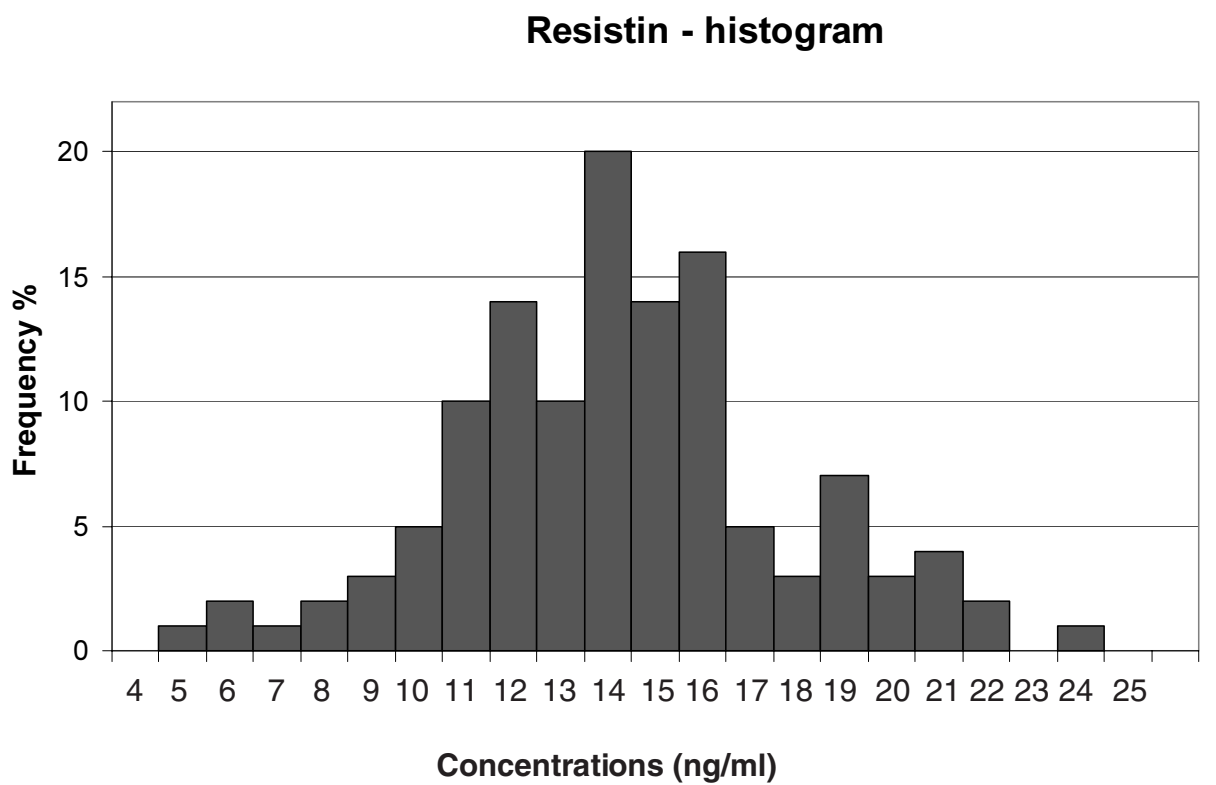

Graph 1. 


\section{CONCLUSION}

Normal resistin concentrations in the serum were determined in 123 non-obese probands without signs of insulin resistance and/or inflammatory disease.

\section{ACKNOWLEDGEMENT}

This work was supported by grant MSM 151100003 from the Ministry of Youth and Education of the Czech Republic.

\section{REFERENCES}

1. Wang H, Chu WS, Hemphill C, Elbein SC ( 2002) Human Resistin Gene: Molecular Scanning and Evaluation of Association with Insulin Sensitivity and Type 2 Diabetes in Caucasians. J. Clin Endocrinol Metab. 87, 2520-2524.

2. Shojima N, Sakoda H, Ogihara T, Fujishiro M (2002) Humoral Regulation of Resistin Expression in 3T3-L1 Mouse Adipose. Diabetes. 51,1737-1744.

3. Growth Hormone Rapidly Induces Resistin Gene Expression in White Adipose Tissue of Spontaneous Dwarf (SDR) Rats. Endocrinology. (2002) 143, 2445-8.
4. Li J, Yu X, Pan W, Unger RH (2002) Gene expression profile of rat adipose tissue at the onset of high-fat-diet obesity. Am J Physiol Endocrinol Metab. 282, 1334-41.

5. McTernan PG, McTernan CL, Chetty R, Jenner K, Fisher FM, Lauer MN, Crocker J, Barnett AH, Kumar S (2002) Increased resistin gene and protein expression in human abdominal adipose tissue. J Clin Endocrinol Metab. 87, 2407.

6. Janke J, Engeli S, Gorzelniak K, Luft FC, Sharma AM (2002) Resistin gene expression in human adipocytes is not related to insulin resistance. Obes Res. 10, 1-5.

7. McTernan CL, McTernan PG, Harte AL, Levick PL, Barnett AH, Kumar S (2002) Resistin, central obesity, and type 2 diabetes. Lancet 359, 46-7.

8. Nagaev I, Smith U (2001) Insulin resistance and type 2 diabetes are not related to resistin expression in human fat cells or skeletal muscle. Biochem. Biophys. Res. Commun. 285, 561-4.

9. Way JM, Gorgun CZ, Tong Q, Uysal KT, Brown KK, Harrington WW, Oliver WR Jr., Willson TM, Kliewer SA, Hotamisligil GS (2001) Adipose tissue resistin expression is severely suppressed in obesity and stimulated by peroxisome proliferator-activated receptor gamma agonists. J. Biol. Chem. 276, 25651-3.

10. Ling C, Kindblom J, Wennbo H, Billig H (2001) Increased resistin expression in the adipose tissue of male prolactin transgenic mice and in male mice with elevated androgen levels. FEBS Lett. 26, $147-50$.

11. Bastard JP, Maachi M, Van Nhieu JT, Jardel C, Bruckert E, Grimaldi A, Robert JJ, Capeau J, Hainque B (2002) Adipose Tissue IL-6 Content Correlates with Resistance to Insulin Activation of Glucose Uptake both in Vivo and in Vitro. J. Clin. Endocrinol Metab. 87, 2084-9.

12. Phoenix: http://www.phoenixpptide.com/Catalog\%20Files/Resistin/ resistin.htm 